\title{
Enhancing the Value Chain of Exporting Agricultural Products in the Southeastern Vietnam Focus Economic Region-SOFER
}

\author{
Pham Chau Thanh, Vo Phuoc Tan ", Pham Xuan Thu \\ College of Foreign Economic Relations (VSR), Vietnam
}

Copyright $(2017$ by authors, all rights reserved. Authors agree that this article remains permanently open access under the terms of the Creative Commons Attribution License 4.0 international License.

\begin{abstract}
The Southeast Region of Vietnam is considered the focus economic region with dynamic development, the growth of economy to be high and sustainable, taking the lead in the industrialization and modernization, and leading economic development of the whole country. Laying the region as a bridging role for Mekong Delta and Central Highlands region, the Southeast Region is leading the development of a number of important sectors, and contributing to improve the quality, efficiency and international competitiveness and incentive for social-economic development of the country. Researching to enhance the value chain of exporting agricultural products in the Southeast Vietnam focus economic region is to help change views of agricultural production aiming to consumer market of agricultural products before carrying out production and business. Besides, the study will help to show the needs of the market and thereby to enhance the efficiency of management in production and business, and determine the level of investment and support to enhance the value chain of the value chain of exporting agricultural products of the region. The research results also suggest the particular solutions to remove difficulties in the formation of the value chain to ensure that exporting agricultural products of the region to meet the needs of the exporting market and set up the value chain towards sustainability.
\end{abstract}

Keywords Value Chain, Exporting Agricultural Products

\section{Introduction}

The Southeast Focus Economic Region (SOFER) covers 6 provinces and municipalities appurtenant to both the southwest and the southeast part of Vietnam, namely Ho Chi Minh City, Dong Nai, Ba Ria - Vung Tau, Binh Duong, Binh Phuoc and Tay Ninh. It has $17 \%$ of the nation's population and more than $8 \%$ of the country's surface area. It contributes more than $42 \%$ GDP, approximately $40 \%$ of export income, and nearly $60 \%$ of the national budget income. SOFER is the largest economic region, the leading industrial and agricultural center of the nation.

Agriculture, one of the basic economic sectors of Vietnam's Southeast Region, is important in socio-economic development in our country. With near $40 \%$ of the total value of the exporting agricultural products of the whole country, in recent years, the agricultural sector of Vietnam's Southeast Region has developed rapidly in the production of goods and for export. However, the growth of the agricultural sector the Southeast Region is not sustainable, the exporting price of the agricultural products is not stability, the added value of the exporting agricultural products is low.

One of the main reasons is due to incomplete supply chains for agricultural products and lack of improvement in enhancing the value of the stages of production and supply of agricultural products for export of Vietnam in general and the South East region in particular [1], [7], [8], [9], [11]. The concept of the value chain has been the developed countries apply in decades to bring products to market efficiently, especially agricultural products. In Vietnam, this approach has been known and widely used after year 2000 . The manner to approach the concepts of the value chain are mentioned by many different authors as Kaplinsky (1999), Kaplinsky vaMorris (2001), Porter ( 1985), Gereffi (1994, 1999), G. Gereffi vaJ. Humphrey, et al. (2003) and as chain link: "Value Links" by GTZ (2007) (Deutsche Gesellschaft für Technische Zusammenarbeit - German). Value chain, is seen as a value chain analysis, is a concept from business management first described by Michael Porter and universal (1985) in his book "Competitive Advantage: Creating and Sustaining Superior performance".

The approach of the value chain in this article is a set of activities by many different agents involved in the implementation (input suppliers, collectors, processors, 
companies, wholesalers, retailers ... ) to produce a product and then sell to consumers in domestic and export (global approach).The content of this article will focus on the evaluation of agricultural export activities and proposing solutions to enhance the value chain of agricultural exports in the Southeast region of Vietnam.

\section{Research Method}

Value chain, also reality on agricultural production, the authors conducted to research matters related to supply chain and value chain of exported agricultural products The Southeast Focus Economic Region of Vietnam- SOFER. To research the topic, the authors considered, researched based on some criteria, including:

- The situation of agricultural exports in SOFER, including Area and Output (Export quantity) of the exporting agricultural products of provinces in SOFER, the exporting value of agricultural products of SOFER.

- The challenges of production and trade activities including weaknesses in the production and export of agricultural products of SOFER.

- Qualitative analysis method [Creswell, John (2008), Research Design: Qualitative, Quantitative, and Mixed Methods Approaches]: Using the mapping tool [Jon Hellin and Madelon Meijer (2009), Guidelines for value chain analysis] to assess the value chain of factors such as manufacturers, processing, trade and consumption; the characteristics of the factors involved, the profit structure and cost.

- Quantitative analysis method [Creswell, John (2008), Research Design: Qualitative, Quantitative, and Mixed Methods Approaches]: Using the analysis tools in investment costs, cost analysis, revenue, value added, gross profit, depreciation, net profit to analyze and assess Distributions interest between the factors in the chain from the survey results of the previous work.

The article is based on information collected from the group and aggregate data from the General Statistics Office, Ministry of Agriculture and Rural Development, the professional associations [Appendix 1] and the actual survey [Appendix 2] in the household as a basis for analysis and review.

The research was conducted in beginning of 2015 , including desk research combined with fieldwork in the country. Information includes trade statistics, area and output data of provinces of SKER and of the whole country. Data on the situation of agricultural exports, exports are generally accessible from the website of the Statistical Office (www.gso.gov.vn) and the Ministry of Agriculture and Rural Development (www.argoviet.gov.vn).
These policies [Appendix 2] and methods implemented in the context of research papers based on the development strategy of the Government, the industry [Appendix 2, and 3] and the Association [Appendix 1].

\section{Value Chain of the Exporting Agricultural Products of Vietnam's Southeastern Focus Economic Region}

\subsection{Area and Production quantity of the Main Agricultural Products}

Area and yields of some major crops and export of the country's Southeastern Region are given in Table 1. The export agricultural products in Vietnam are mainly Fisheries, Rice, Wood, Rubber, coffee, cashew, and pepper. According to statistics of the General Statistics Office of Vietnam (GSO) and the Ministry of Agriculture and Rural Development (MARD), the area and production quantity of the main agricultural products in 2014 compared with 2013 such as: the aquaculture of the whole country increased $11.3 \%$ of production area and $4.8 \%$ of quantity, wood was increasing $6.1 \%$ of production area and $3.3 \%$ of quantity, Rubber was correspondingly $2.0 \%$ and $0.7 \%$, Coffee with $0.7 \%$ and $1.0 \%$, Cassava with $1.3 \%$ and $4.8 \%$, Fruit crops with $3.8 \%$ and $7.8 \%$, and especially Pepper had sharply increasing with $21.4 \%$ of production area and $13.0 \%$ of quantity; however, production area of Rice and Cashew decreased $1.1 \%$ and $3.1 \%$, but the production quantity of them was still increasing with $2.2 \%$ and $25.2 \%$ therefore conditions of climate for planting were good in 2014.

SOFER own major agricultural products, such as rubber with a production area of 435 thousand hectares $(44.5 \%$ of the whole production area) and 435 thousand tons of production (accounting for $45.8 \%$ of the country); corresponding to 186 thousand cashew products (accounting for 59.8\% of the country) and 167 thousand tons (accounting for $60.1 \%$ of the country); Pepper was 28 thousand hectares $(41.2 \%$ of the whole country) and 51 thousand tons (accounting for $41.8 \%$ of the country); and Cassava is 92 thousand hectares (16.9\% of the country) and 2.4 million tons ( $25 \%$ of the country).

\subsection{Value of the Export Agriculture}

\subsubsection{Value of the Export Agriculture of Whole Country}

Agricultural export value of Vietnam in 2014 increased 1.6 times compared with 2010. The total value of agricultural exports of the whole country in 2014 was \$USD 30.54 billion, the export value growth rate was $15.4 \%$ per year in stage $2010-2014$, the average proportion of agricultural export in total export turnover of the whole country was $23,5 \%$ per year.

Structure of exports, 2010 if Vietnam has 6 items over 
\$USD 1 billion of which is 1 item on the \$USD 3 billion in export value of agricultural production in key export, in 2014, our country's agricultural export with 10 products worth over \$USD 1 billion of which 4 items worth over \$ 3 billion in exports. With 10 major exports of aquatic products in 2012, such as cashew nuts, coffee, rice, rubber
$\&$ products, wood \& wood products, pepper, Cassava \& cassava products, vegetables and produce rubber products have brought in \$USD 129,6 billion worth of exports in the stage 2010 - 2014, accounting for $95 \%$ of total export value of agricultural products.

Table 1. Area and output of the main agricultural products in SOFER

Unit: 1,000

\begin{tabular}{|c|c|c|c|c|c|c|}
\hline \multirow{3}{*}{ Agricultural Products } & \multicolumn{2}{|c|}{ Whole country (W) } & \multicolumn{2}{|c|}{ Southeast Region (SOFER) } & \multicolumn{2}{|c|}{ W/SOFER } \\
\hline & Area & Production quantity & Area & Production quantity & Area & Production quantity \\
\hline & (Ha) & (Ton) & (Ha) & (Ton) & $(\%)$ & $(\%)$ \\
\hline Aquaculture & 1,280 & 3,413 & 53 & 107 & 4.0 & 3.1 \\
\hline Wood $\left(\mathrm{m}^{3 *}\right)$ & 13,862 & $5,608^{*}$ & 472 & $340 *$ & 3.4 & 6.1 \\
\hline Rice & 7,899 & 44,076 & 280 & 1,346 & 3.5 & 3.1 \\
\hline Rubber & 956 & 949 & 425 & 435 & 44.5 & 45.8 \\
\hline Coffee & 635 & 1,290 & 45 & 102 & 7.1 & 7.9 \\
\hline Cashew & 311 & 278 & 186 & 167 & 59.8 & 60.1 \\
\hline Cassava & 544 & 9,742 & 92 & 2,434 & 16.9 & 25.0 \\
\hline Pepper & 68 & 122 & 28 & 51 & 41.2 & 41.8 \\
\hline Fruit crops & 780 & 7,730 & 135 & 1,345 & 17.3 & 17.4 \\
\hline
\end{tabular}

Source: From www.gso.gov.vn and www.argoviet.gov.vn, MARD, 2014

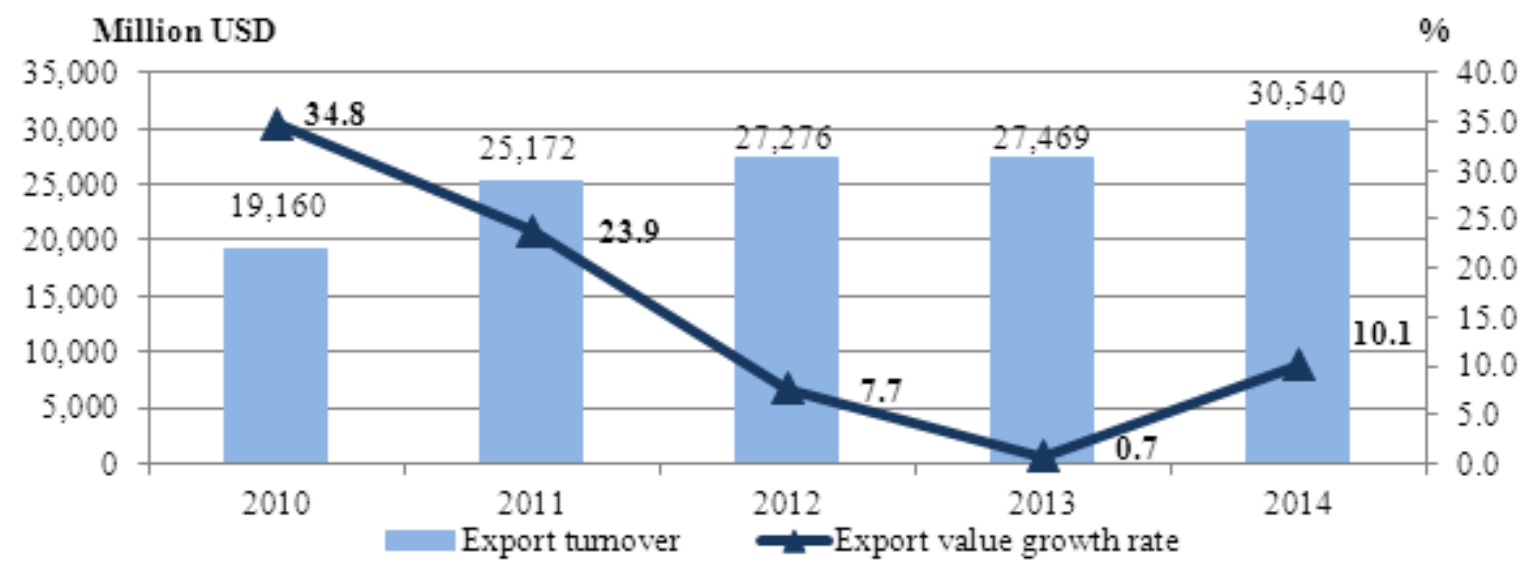

Source: From GSO, MARD, 2014

Figure 1. Export turnover and Export value growth rate of Vietnamese's agricultural products
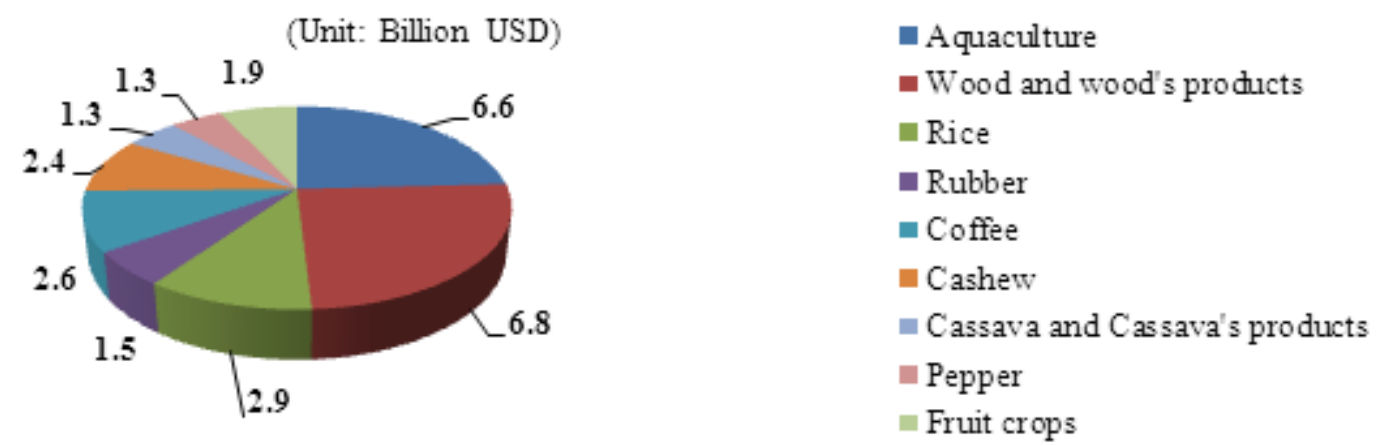

Source: From GSO, MARD, 2014

Figure 2. Export structure of Vietnamese's agricultural products 
Regarding export market, before 2010 our agricultural goods exported to about 80 countries, in 2014, Vietnam exported agricultural products to nearly 160 countries around the world, and expanding from North America, Europe, Northeast Asia, Australia to South America, Africa and West Asia. Most of them are the U.S., Japan, China, Switzerland, Australia, Singapore, the Netherlands, the UK and the ASEAN Community ... One of the greatest successes of our agriculture after the WTO has opened markets, in addition to the "difficult market" as U.S., EU, Japan, many agricultural commodities have increasingly penetrated into Africa, South Asia and South America, this is the remarkable result of the efforts export of local enterprises.

In summary, Vietnam exporting agricultural product has made significant progress in recent years and contributed greatly to the development and the socioeconomic stability of the country.

\subsubsection{Value of the Export Agriculture in Provinces in SOFER}

Agricultural export turnover of the SOFER's provinces has significant growth between 2010 and 2014 in which, Tp. HCM increased 2.5 times from $\$ 2.1$ billion in 2010 to $\$ 5.5$ billion in 2014, corresponding to Binh Phuoc province agricultural turnover doubled from USD 185 million to USD 398 million, Xining increase 1.6 times from 249 million to 401 million, and increased by 1.3 times Pacific from 1.76 billion to 2.35 billion. The rest of the province also has good turnovers.

Regarding the contribution rate, exports of agricultural products under SOFER has contributed significantly to the agricultural exports of the country ranging from $28.6 \%$ to $37.7 \%$, the average contribution to agricultural exports of the country the period $2010-2014$ was $34.5 \%$ / year; contribute to merchandise exports of the whole country is from $7.4 \%$ to $9.1 \%$, the average contribution to overall export of the country stage $2010-2014$ was $8.0 \%$ / year.

\subsection{Value Chain of the Exporting Agricultural Products}

\subsubsection{General Value Chain}

Overall value chain of most agricultural exports in Vietnam and Southeast area consist of 5 major phases: Input, Production, Collection, Industrial processing, and Exporting, as shown in Figure 1. Accordingly, taking export unit price of products common to the cost price and the value added (in \%) for each phase. Input operation phase includes inputs for agricultural production, such as preparation of seeds, fertilizers, soil improvement; prepare a pole or digging ponds, and the cost of materials for the first year before exploitation. Phase Input costs are amortized on a phase-average number of years of other operators such crops; Production phase is the phase care about fertilizers, pesticides, weeding ... for one unit of product, including the cost of the product harvested; Collection phase is the retail buyers, dealers or processing plants. This stage is only the added value of this activity, not including logistics expenses; Industrial processing phase includes pre-processing operations (air and dry - performed by farmers or processors performing), preservation packaging and further processing at the processing plant; Exporting phase distribution only uses the value-added agricultural products exporters enjoy.

Logistics in the value chain include cargo handling, cargo from the garden to the agent or agents between level 1 and 2 or between dealers to processing plants, preserved during transport transfer or export, and implementation of procedures relating to the sale and export of agricultural commodities. This fee is separated from the Collection phase stage, Industrial processing, and Exporting.

Table 2. Export turnover (ET) of the agriculture of provinces in SOFER

Unit: Million USD

\begin{tabular}{|c|c|c|c|c|c|}
\hline Export value & 2010 & 2011 & 2012 & 2013 & 2014 \\
\hline ET of Southeast Region (SOFER) & 6,525 & 7,188 & 9,332 & 10,369 & 11,522 \\
\hline Binh Phuoc & 185 & 223 & 249 & 431 & 398 \\
\hline Tay Ninh & 249 & 328 & 432 & 430 & 401 \\
\hline Binh Duong & 1,875 & 1,945 & 2,075 & 2,295 & 2,352 \\
\hline Dong Nai & 1,762 & 1,917 & 2,033 & 2,132 & 2,345 \\
\hline Ba Ria - Vung Tau & 368 & 530 & 407 & 479 & 551 \\
\hline Ho Chi Minh City & 2,086 & 2,245 & 4,137 & 4,602 & 5,475 \\
\hline ET of whole country (W) & 19,160 & 25,172 & 27,276 & 27,469 & 30,540 \\
\hline Total export turnover of whole country (TW) & 71,630 & 96,606 & 114,529 & 132,175 & 150,151 \\
\hline SOFER/W (\%) & 34.1 & 28.6 & 34.2 & 37.7 & 37.7 \\
\hline SOFER/TW (\%) & 9.1 & 7.4 & 8.1 & 7.8 & 7.7 \\
\hline
\end{tabular}

Source: From www.gso.gov.vn and www.argoviet.gov.vn, MARD, 2014 


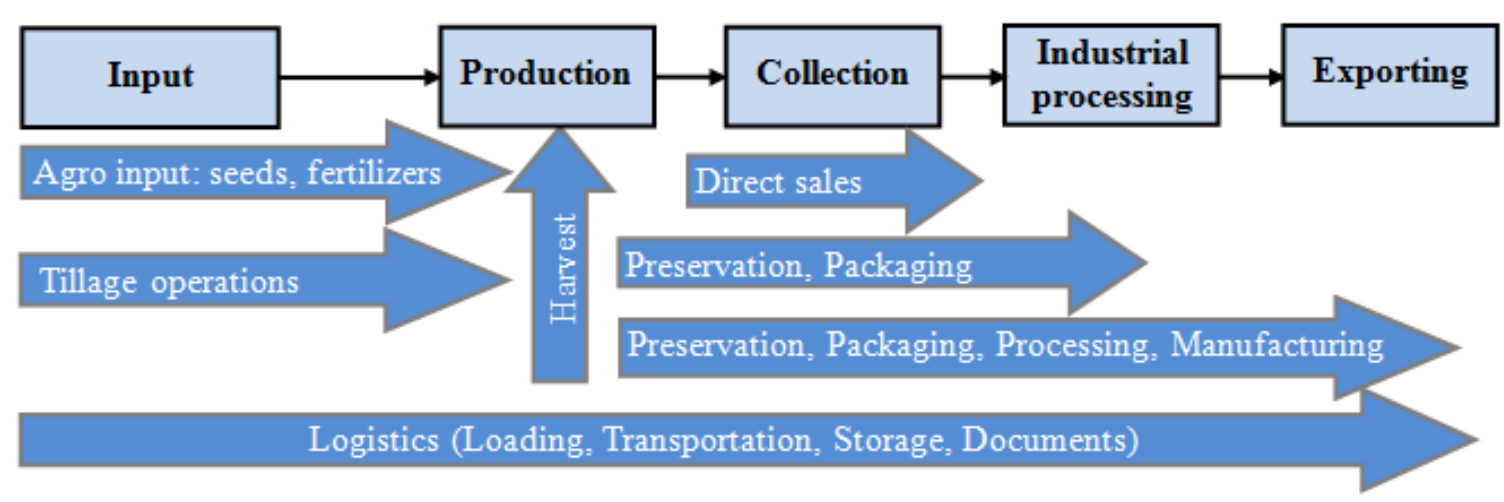

Source: Synthesized from search works on value chains of the exporting agricultural products inside country

Figure 3. Value chain of the most of the exporting agricultural products in SOFER

\subsubsection{The Export Value Chain of the Main Agricultural Products of SOFER}

Based on previous researches on the value chain of the cashew industrial association (2013), Material rubber value chain by Tran Tu Luc (2013), Dried cassava value chain of the Crop Research Institute Southern plantation (2014), and chain black pepper export value of self-survey authors to analyze and assess the value chain of agricultural exports for SOFER.

The authors will conduct the analysis and assessment of the value chain's key export items SOFER follow the main stages of the value chain of agricultural exports in general in Figure 3. The results of each phase value close four stages of agricultural chain's flagship export SOFER given in Figure 4.

Cashew Nuts Value Chain, SOFER (Cashew Nuts

Industry Association, 2013)

The survey results of the authors suggest:

- The cost of logistics (Including cost of Loading, Transportation, Storage, Documents) accounted for $19 \%$ of total export value chain.

- Input phase: input costs accounted for $2 \%$ of the total export value chain: including soil improvement, fertilizer, seedlings, marker ... including the cost of fertilizer and care for trees in 3 - first 5 years.

- Production phase: Manufacturing accounted for $21 \%$ of total export value chain: The value added for farmers during this period accounted for $7 \%$ of the whole value chain for the production costs for the production process and take pepper after this period accounted for $14 \%$;

- Collection phase: Collection 3\% of the total export value chain; Added value to collectors in phase $3 \%$ of the value chain, the cost during this period charged to operating expenses for logistics.

- Industrial processing phase: As the pre-processing operations, peeled and processed into raw cashew nuts. Processing accounted for $51 \%$ of total export value chain. Value added from active status (drying) of $3 \%$, this activity can be carried out by farmers to add value-added products; Value for deep processing operations include cutting bark, dried, classified as $9 \%$; cost of processing operations accounted for $39 \%$;

- Exporting phase: Exports 4\% export value chain. Value added $4 \%$ this period, the cost during this period charged to operating expenses for logistics.

Material Rubber Value Chain, SOFER (Tran Tu Luc, 2013)

The results from the study by Tran Tu Luc (2013) showed that:

- Logistics expenses accounted for $20 \%$ of total export value chain.

- Input phase: input costs accounted for $2 \%$ of the total export value chain: including soil improvement, fertilizers and seedlings ... In fact, the cost of inputs for the cultivation of rubber trees are very high, including land reclamation, care fertilizer and seedlings with tree-care

- Costs in the first 7 years before mining. However, these costs may be recovered after another falls (around 20 years) due to the sale of rubber tree wood.

- Production phase: Manufacturing accounted for $19 \%$ of the export value chain. Added value to farmers this period $13 \%$ of the entire value chain for the production costs of latex accounts for $6 \%$.

- Collection phase: Collection occupied $6 \%$ of the total export value chain; Added value to collectors in the period $6 \%$ of the whole value chain, the cost during this period charged to operating expenses for logistics.

- Industrial processing phase: As activities in latex dewatering, drying and preparation of rubber blocks. Processing accounts for $50 \%$ of total export value chain. Value added in the period accounted for $12 \%$ of the whole value chain, costs for rubber processing activities account for $38 \%$.

- Exporting phase: Exports accounted for 3\% of the total export value chain. Value added 3\% this period, the cost during this period calculated on the cost of logistics operations. 
Black Pepper Value Chain, SOFER (Surveyed by the Authors, 2015)

Results from the actual survey stated:

- The cost of logistics: $17 \%$ of total export value chain.

- Input phase: input costs accounted for $10 \%$, including land reclamation, fertilizers, seedlings, marker ... including the cost of fertilizer and care for pepper in the first 3 years.

- Production phase: Manufacturing accounted for $45 \%$ of total export value chain. Added value to farmers this period was $27 \%$ of the entire value chain for the production costs for the production and care of pepper this period accounted for $18 \%$;

- Collection phase: Collection $4 \%$ of the total export value chain. Added value to collectors in stage $4 \%$ of the value chain, the cost during this period charged to operating expenses for logistics.

- Industrial processing phase: activities included processing, frozen, dried from the fresh pepper black pepper. Processed $21 \%$ of the total export value chain. Value added in the period accounted for $18 \%$ of the value chain, and this activity can be carried out by farmers to add value to the product. Costs for processing activities account for $3 \%$ black pepper.

- Exporting phase: Exports accounted for 3\% of the total export value chain. Value added 3\% this period, the cost during this period calculated on the cost of logistics operations.

Dried Cassava Value Chain, SOFER (Crops Research Institute for Southern, 2014)

The calculation results from the work of the International Crops Research Institute of the South (2014) showed that:

- Logistics expenses accounted for up to $21 \%$ of total export value chain.

- Input phase: Includes activities such as land reclamation, fertilizers, seedlings Input costs account for $8 \%$ of the total export value chain.

- Production Phase: Production 18\% of total export value chain. Value added at this stage $9 \%$ whole value chain for the production cost of cassava accounted for $9 \%$;

- Collection phase: Collection $4 \%$ of the total export value chain. Intermediate values for collectors in the period accounted for $5 \%$ of total export value chain, the cost during this period charged to operating expenses Logistics.

- Industrial processing phase: Activities include pre-processing (drying, smoking) from fresh cassava into dried cassava for export. Processing over $45 \%$ of total export value chain. Value added at this stage and $4 \%$ could be made by farmers, cassava production costs accounted for $41 \%$;

- Exporting phase: Exports accounted for $2 \%$ of total export value chain. Value added this phase $2 \%$ of the total export value chain, the cost during this period charged to operating expenses for logistics.

General assessment, by analyzing four agricultural value chain's flagship export, SOFER suggests costs of logistic operations in Vietnam for the export of agricultural products from $17 \%$ to a high of $21 \%$, while costs this activity in European countries and America only $10-15 \% ; \%$, In Singapore only $8 \%$ of the total export value chain. Production activities of farmers bring added value at just fewer than $10 \%$, unless the product is black pepper is one of the few products in recent years to bring high added value $(27 \%)$ for farmers. Collection activities by many intermediate levels, so even accounting for $3 \%$ to $6 \%$, but it is difficult to reduce or cut out the intermediary. Preliminary processing activities also bring high added value to farmers (increased from $3 \%$ to $18 \%$ ). In addition, the analysis also shows that most agricultural export products of Vietnam in general and in particular SOFER are raw products or preliminarily processed, the processing steps deep into food products or water refreshments to raise value-added agricultural products export has not been focused.

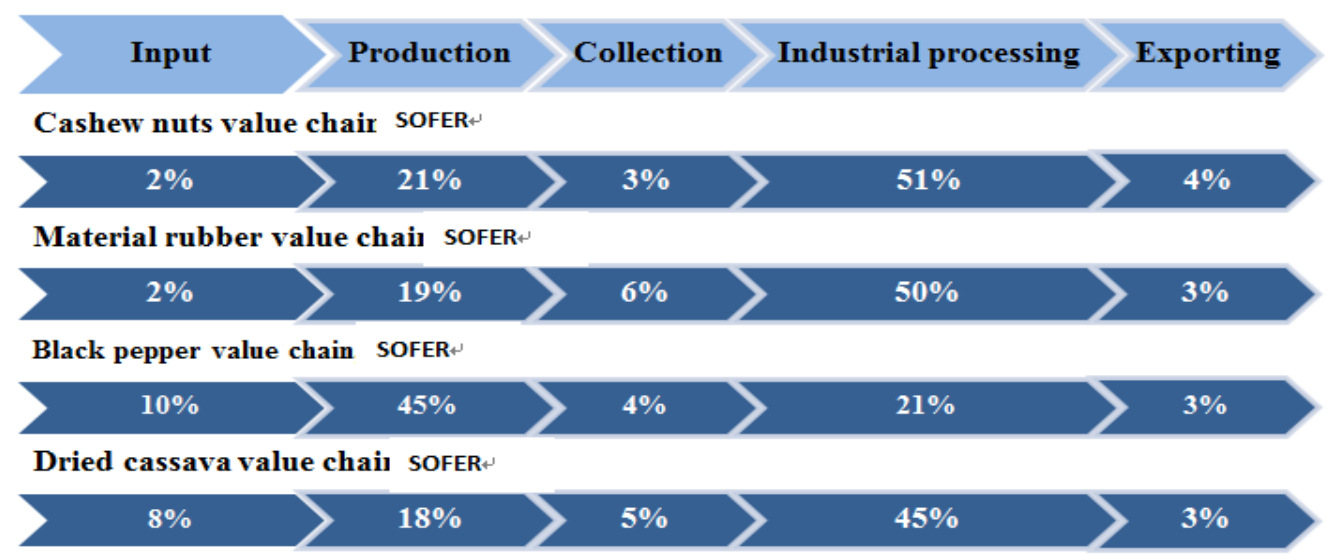

Source: Synthesized from search works on value chains of the exporting agricultural products inside country and surveyed by the authors

Figure 5. Exporting value chain of the main agricultural products of SOFER 


\section{Shortcomings of the Value Chain of Export Products in SOFER}

Export Agricultural Product In Raw

Agricultural products of Vietnam are still exported mainly in raw, less processed products and commodities mainly processed goods such as rice, rubber, coffee, seafood, cashew nuts, pepper ... with the stability of poor quality, difficult to penetrate the consumption of goods of agricultural commodities should not be focused on consumers and hence difficulties in branding.

The Competitiveness of the Export Agricultural Products in SOFER is Low

Consumer market is instable, less diverse and depends on a traditional market, direct export through unofficial channel, which poses many potential risks. The export market is not robust and still reveals many limitations and shortcomings of a fragmented agriculture, missing link, low productivity and quality in the context of increasing competition. The model links from production to consumption between farmers have been now deployed slow, not very efficient.

Fragmented Production and Scientific \& Technological Content is Low

For small-scale production, scattering more than 13 million households in 75 million arable agriculture plots with a total area of 8.4 million hectares of land leads to low productivity, product quality is not uniform, collection of agricultural products is limited. Poor transport system has prevented long-distance transport of raw materials and finished products for production costs increase. The remote processing companies which supply raw materials or the material does not have the focus. In addition, the technology investment for harvesting, processing, storage is limited, leading to the loss rate, high damage, heterogeneous goods, packaging materials not good cause large losses in transportation, processing and reducing product quality.

\section{Technical Barrier to Trade (TBT)}

This is a big challenge, not only for traditional exports such as fish, rice, rubber, cashews ... but also for new export vegetables, meat products, milk and fruit ... as required to meet the full range of technical standards and standards of safety and hygiene, food importing countries. Vietnam was a country in the rate agricultural product imports declined highest for EU market because of high antibiotic residues, rice contains acetamiprid.

Investment in Agriculture is Limited

According to reports from Ministry of Agriculture and Rural Development, investment in agriculture from the state budget and government bonds in 2010 - 2015 is \$USD 23.81 billion, but mainly focused on irrigation and land $65 \%$ of rural infrastructure, investment in agriculture - forestry - fishery accounts for the remaining 35\%. Capital of foreign direct investment (FDI) registered in agriculture accounted for only $1.63 \%$ of the total investment. Total ODA investment in agriculture, rural areas accounted for $14.25 \%$ of total capital. Especially investment funds for science and technology in agricultural production in our country is still very low compared to other countries in the region, on average, $\$ 5 /$ person (2010) compared to $\$ 20$ in China (2008) and \$1000/person of South Korea (2009) (mpi.gov.vn). The modest investment in agriculture will reduce the motivation to develop the production of agricultural product goods from diversity to improve quality in order to increase the advantage in a commercial environment with increasing levels of competition.

\section{Solutions for Enhancing the Value Chain of Exporting Agricultural Products in SOFER}

\subsection{Development Orientation}

Southeast Focus Economic Region (SOFER) are considered economically developed regions with stable dynamic economic growth rates, taking the lead in the national industrialization and modernization of the country, and in the development of the national economy. It is a region that bridges the Mekong Delta and Central Highlands region together. It leads the development of a number of important areas, contributes to improving the quality, efficiency and international competitiveness, and motivates economic development - economic development of the country.

The Southeast Focus Economic Region (SOFER) is Ho chi Minh City which is the great service center for Southeast Asia in finance, commerce, tourism, international exchanges; is the center of education and training of human resources, especially high-quality human resources; concurrently transfer centers and science and technology applications in agriculture leading the country.

\subsection{General Solutions}

First, strengthen the communicating innovation and market forecasts:

Investing in modern market forecast technology is crucial. Besides, we should form a coordination mechanism not only between authorities and industry associations but also establish communication channels with farmers, processing enterprises, agricultural procurement. Mechanisms for information collecting and process are also needed towards innovation going into the sector.

Second, we should establish and create the organic agriculture with safe products:

There should be measures to overcome the current fragmentation of land to facilitate the mechanization, 
scientific applications - the new technology goes into agricultural production goods, such as: extending the land limits, increasing duration of use land use, promoting market transactions of agricultural land to accelerate the transfer, conversion, leasing, capital contribution, land for lease...

Next, to ensure the quality of exported agricultural products (about food safety and high nutrition content) is to carefully examine areas with existing plants. The plant area which results in higher productivity and better quality will be retained for long-term development, but the area is not suitable to be discarded. It should apply the methods of organic agriculture, and absolutely no use of inorganic fertilizers, pesticides and antibiotics. However, this does not mean applying the outdated agricultural production, which must select the best from traditional farming, improve them with modern scientific knowledge. Having such guarantees uniform product quality, meet increasingly demanding requirements of the market, decide the success in the marketplace.

Rushing formed standard systems, the laboratory evaluation of the quality of agricultural products. Appreciate and strengthening inspection and supervision authorities handle "strong hand" the intentional application of farming techniques that are harmful to the environment, as "dirty" agriculture. The state should actively control production in disease-free areas in order to create safe agricultural goods. Developing agro products vertically, switch strategy to increase the number of strategic export product export quality VIETGAP/GMPs - GLOBAL GAP VASEP to add value to the product.

Safe agriculture not only reflects in safe produce, ensures nutritional and no harm to the users, but also brings no harm to the producers, avoids degradation and pollution. With the current level of development and in many years, we should focus on developing organic agriculture for some specialty crops. To develop in that direction, we need to address many issues, including the awareness of farmers and of the State management agencies play a vital role

Third, strengthening the connection between 5 factors:

Farmer, Entrepreneur, Scientist, Bankers, the State, in which the State acts as a mentor of the agricultural value chain of South East region on a global scale. Enterprises must also search consuming markets, and bring about ordering seed farmers market demand business model; is a friend of farmers, ensuring simultaneous input and output of agricultural products. The Ministry of Agriculture is responsible for regional planning aquaculture, investing more in science and technology to create the varieties with high efficiency. Ministry of Industry and Trade should adapt measures to promote enterprise become the mainstay in the production development, well-organized distribution network throughout. The Bank has supported the policy lending rate to ensure crop production capital. The Ministry of Industry needs to reduce and gradually eliminate administrative procedures unnecessary or hinder businesses to export agricultural products.

Fourth, we need to completely solve the problem frugal "good harvest but the crops' price drop":

to promote agricultural restructuring towards rational planning between production scale associated with market demand consumption structure, strengthen links within the region and between regions linked to a reasonable division of labor, creating large production models, new varieties, high productivity, reduce costs, build a network of direct distribution of agricultural products Management from field to consumer, competition on the domestic market and export market shift, effective exploitation agreements that Vietnam has signed FTAs with other countries.

Fifth, technological modernization and preservation processing of agricultural products:

Only when agriculture is managed in the production value chain, we can raise the value of agricultural products. Thus, the stages from raw material production, processing, preservation to marketing of products must be coherent with each other. Accordingly, business relationship farmers should be of particular interest, namely the policy mechanism to support businesses, farmers invested heavily in post-harvest technology, preservation and processing in order to limit loss mechanism, enhance the value of agricultural products.

To robustly develop processing industry, we need to solve many problems, which are mainly:

- Construction planning concentrated material zones, large-scale export-oriented. Since then, the focus of intensive investment and application of scientific achievements and new technologies to meet the export processing requirements.

- Strengthening development investment agricultural processing industries in association with the raw, cold storage equipment, remote projection equipment sterilization and quarantine, isolation,... There are incentives to stimulate sale of all economic component, technology investments in processing agricultural products for export to gradually shift from export method of raw materials, semi-processed products, to export the processed products have value content high rise.

Sixth, attracting strong Foreign Direct Investment Capital in the agricultural sector:

In 10 years, the agriculture sector attracted only US \$ 5 billion of capital, accounted for $10 \%$ of projects and $3.3 \%$ of FDI in the country. Of which only about $\$ 2$ billion was disbursed, nearly $30 \%$ of the projects is dissolved ahead of schedule. Many projects had slow deployment. This happens because the planning sector, region and some important products that have not been built, deployed, instability should not create conditions for the construction 
of the portfolio, the program calls for FDI. Information about the investment project also calls for a brief, lack of precision, it is not attractive, attracted the attention of investors. Hence, building investment promotion fund, improve efficiency promotion activities in the fields of agriculture, forestry, fisheries, policy specifies preferential vocational training must be seen as what to do immediately.

Seventh, organized markets, build distribution network system of agricultural products:

Many experts point out this is an important link, but has always been a weak point today. These objectives should be focused on the period 2010 - 2015 are:

- organize a good circulation of goods in order to create the premises within the production and division of labor in agriculture by expanding the service processing industries besides agriculture, and to create the premise outside (especially expanded export markets) to bring the production of goods in rural areas on a large scale, access to world markets.

- Starting from consumption, demand from domestic and foreign markets to planning production and circulation to "sell what the market wants, not what you can sell." Restructuring agricultural production towards production tied to the market, on the basis of maximizing the comparative advantages of regional and local.

Eighth, branding, geographical indications for agricultural products in Vietnam:

Strategies need to build a brand for the agricultural products of Vietnam's strong enough on the world market, especially for export products now occupies a leading position in the world today, such as rice, coffee, pepper, cashew nuts, tea, fruits, ... in order to bring modernize agricultural production Vietnam toward increasing sustainable value and should soon deployed two strategic breakthrough the branding for Vietnam agricultural products and of breeding high-quality agricultural products; perform business promoting specialty crops to meet the demand - not only the preferences of domestic consumers but also exporting in the context of the changing tastes of the current

In fact, there are up to $85 \%-90 \%$ of our country's agricultural products in the world market through the intermediary must equal the "brand" abroad, so the low price, be coerced ... is the common case. Thus, Vietnam's agricultural products tries to earn customer's reputation, brand, and then protect that brand to be able to be present and participate in the chain of consumption of agricultural products in the world.

Going forward, the industry associations of Vietnam agro-forestry products should be organized sector introduce their products to consumers in a number of localities in the countries that export goods to Vietnam direction.
Depending on the actual conditions and specific strategies of each business that processes built, brand development will undergo operational steps and different order. However, brand development should seek consensus in the long-term and there is a certain guarantee to have enough financial stability to promote dynamic competitive edge for some product groups and market segments clear objectives.

Ninth, strengthen the competitiveness of Vietnam agricultural exports:

Since agricultural exports are facing concerns about technical barriers TBT and especially to compete with imported agricultural products joining economic integration, the import tax rate of $0 \%$ returns. Vietnam always been proud to be the leading country in the export of agricultural products in the world with our country's rice was quickly ranked 2nd in the world powers in the export of rice and is always in the "top 3" during 1 / 4 centuries. After Rice with 5.000 ha farming area in a short time, Vietnam pangasius was "swimming" nearly 150 countries and territories, accounting for $98 \%$ market share of global export fish. Along with rice and fish, International Coffee Organization (ICO) has confirmed that Vietnam has surpassed Brazil and became the number one coffee exporter in the world. Similarly, pepper has occupied position 1 while exports almost 5 times higher than India and Vietnamese's Cashew export has lead the world.

Rubber production quantity of Vietnam has been ranked in No. 4 of the world, with over 1 million tons each year. So it can affirm that with vision, bravery and wisdom Vietnam world is facing a lot of change to change yourself in order to ensure the income of those who make this happen for agriculture Vietnam.

Tenth, enhance connectivity and international share in production and export of agricultural products:

The world economy is functioning in a model of global value chains, so our country's economy should be restructured in the direction of Vietnam for excellent role in the production sector of the whole value chain bridge. It should do so while mentioning a certain product in the global value chain, the world immediately remember to Vietnam and not one other country with quality products and unbeatable prices.

Compared to some countries in Southeast Asia, Vietnam has natural conditions and agricultural structures are similar, but these countries have advantages over Vietnam at the scientific level - technological and experience in international trade activity. In such conditions, to ensure the efficiency of exports and enhance the competitiveness of agricultural products, would be important to expand international links in both production and exports. Relations link may include the following major contents:

- Co-operation in the field of scientific research technology to create plant varieties and animal breeds have high competitiveness. 
- Coordinate system construction services Plant Health Inspection Service export according to international standards.

- Attraction of foreign direct investment into the development of agriculture and rural areas. Coordinating trade policies of countries in the region promote agricultural exports.

- To form industry associations to coordinate their actions and share in the international market. Innovation support policies oriented agricultural development policy must reflect the lives of farmers, ensuring uniform policies from production, quality, processing, distribution, export

- Forming a base for agricultural production scale, focus, modern, having close links along the value chain. Having so can we ensure the quality and competitiveness of agricultural products of Vietnam on the domestic market and export-oriented with large quantity.

\subsection{Proposing the Model for the Value Chain of the Export Agricultural Products}

Based on surveys outcomes from agricultural production activities in SOFER, we need to increase the value of agricultural export chain, value chain model proposed export as Figure 6 below. The model emphasizes the research activities of the value chain in manufacturing and exporting from the seedlings to the production, processing and consumption market research for each specific type of agricultural product. The model also emphasizes training farmers to operate their agricultural production to increase knowledge and understanding of sustainable development for each type of agricultural products. In addition, it also focuses on the close linkages in the manufacturing, service support, application of science and technology in agricultural production, market research and understanding the needs coordination market and distribution channels forming closed from the farmer to the final consumer.

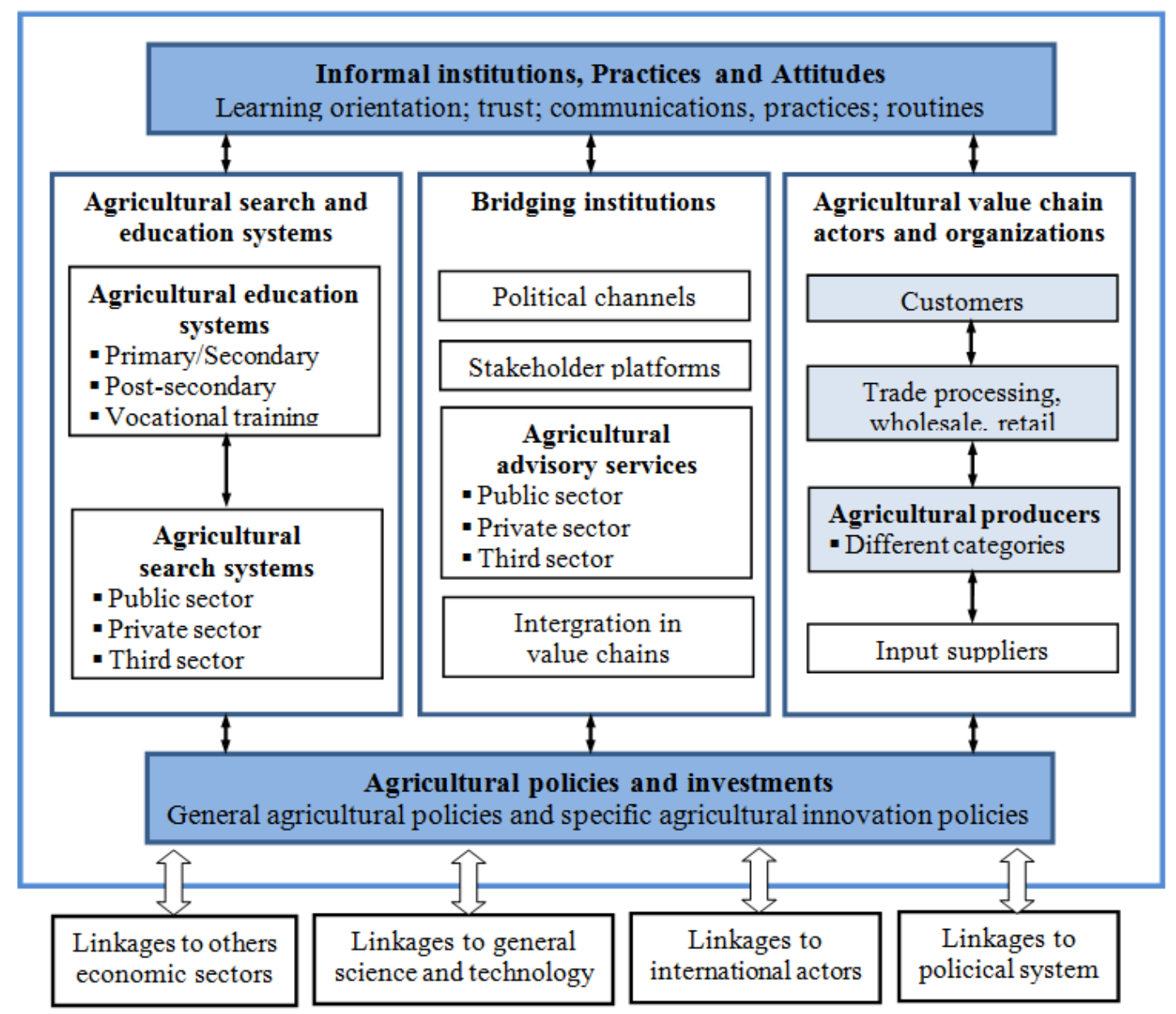

Source: Proposed by the authors

Figure 6. Model for the value chain of the export agricultural products 


\section{Conclusions}

This paper has analyzed and assessed the situation of production and export activities of main agricultural products of Vietnam in general and of SOFER in particular, and showed that the quantity and export value of agricultural products of Vietnam and SOFER have increased rapidly in recent years. Beside the paper also analyzed and evaluated four value chains of the four main export agricultural commodities in SOFER, the results of research have indicated the causes of shortcomings of the value chains of export products in SOFER, and suggested solutions to enhance the value chains of the export agricultural products in SOFER particular and of Vietnam in general.

In summary, the rapid globalization of the agricultural markets has led to the generation of new production and distribution systems, as well as new consumption patterns. One of the objectives of modern agriculture is to reduce to the barest minimum the problems associated with agricultural loss, wastages and output underutilization by ensuring an efficient optimization of all the linkages between the producer and final consumer through the value chain. Value chain of the export agricultural products can be defined as a strategic partnership among inter-dependent businesses that collaborate to progressively create value for the final consumer resulting in a collective competitive advantage. The basic characteristic of a value chain is market-focused collaboration; different business enterprises working together to produce and market products and services effectively and efficiently by allowing businesses to respond to the marketplace through linking production, processing and marketing activities to meet market demands. Agricultural food value chains are designed to increase competitive advantage through collaboration in a venture that links producers, processors, marketers, food service companies, retailers and supporting groups such as shippers, research groups and suppliers. One of the central ideas of the agricultural value chain is the differentiation of the total agro system and the specialization of each element so as to optimize the entire system.

\section{Appendix 1}

In Appendix 1, the authors surveyed associations, Industry and Trade Departments, and Agriculture and Rural Developments about point of views production activities, trade, consuming markets, export costs and prices of export agricultural products and polices of Government on production and trade activities to export agricultural products of Vietnam in general and SOFER in particular.

A.1/ The list of Vietnamese's associations surveyed:

- Vietnam Cashew Association (VINACAS);

- Vietnam Cassava Association (VICAAS);

- Vietnam Pepper Association (VPA);

- Vietnam Pepper Association (VRA);
- Vietnam Food Association (VFA);

A.2/ The list of Vietnamese's Industry and Trade Departments surveyed:

- Binh Phuoc Industry and Trade Department;

- Tay Ninh Industry and Trade Department;

- $\quad$ Binh Duong Industry and Trade Department;

- Dong Nai Industry and Trade Department;

- Ba Ria - Vung Tau Industry and Trade Department;

- Ho Chi Minh City Industry and Trade Department;

A.3/ The list of Vietnamese's Departments surveyed:

- $\quad$ Binh Phuoc Agriculture and Rural Development;

- Tay Ninh Agriculture and Rural Development;

- Binh Duong Agriculture and Rural Development;

- Dong Nai Agriculture and Rural Development;

- Ba Ria - Vung Tau Agriculture and Rural Development;

\section{Appendix 2}

Form $A_{0}$

\section{B1. SURVEY FORM}

\section{(FOR VALUE CHAIN OF EXPORT AGRICULTURAL PRODUCTS)}

\section{(INFORMATION FOR PRODUCTION FAMERS)}

\section{Kính thưa Ông/Bà.}

Kính mong Ông/Bà dành it thòi gian cung cấp các thông tin về hoạt động sản xuất nông sản. Nhũng thông tin quý báu của Quý Ông/Bà sẽ đuợc bảo mật tuyệt đối và chỉ được sử dụng để tổng hợp, phân tích, xủ lý chung và vào muc dich nghiên cứu khoa học.

Xin Ông/Bà vui lòng cho biết một số thông tin:

Please tell some information:

\section{GENERAL INFORMATION}

1. Name of production owner (famer):

2. Address:

3. Kind of agricultural product:

4. Type of production:

\begin{tabular}{cccc}
\hline Type & Individual & Co-operative & Linked \\
\hline $1 \square$ & $2 \square$ & $\square$ \\
\hline
\end{tabular}

\section{INFORMATION ON PRODUCTION}


Question 1. The area of the crop being planted?

\begin{tabular}{|c|c|}
\hline Under 1ha & $1 \square$ \\
\hline From 1ha to under 3ha & $2 \square$ \\
\hline From 3ha to under 5ha & $3 \square$ \\
\hline From 5ha to under 10ha & $4 \square$ \\
\hline Upper 10ha & $5 \square$ \\
\hline
\end{tabular}

Question 2. The origin of seedlings being planted?

\begin{tabular}{|c|c|}
\hline Propagation & $1 \square$ \\
\hline Buy from other farmers & $2 \square$ \\
\hline Buying from private facilities & $3 \square$ \\
\hline Buy from local agriculture and rural developments; & $4 \square$ \\
\hline From other sources & $5 \square$ \\
\hline
\end{tabular}

Question 3. Could you please tell about Costs, Profit in new plant stage for $1 \mathrm{ha}$

\begin{tabular}{|c|c|c|}
\hline Criteria & Unit & Amount (VND) \\
\hline Seeds & Tree & \\
\hline Fertilizers & Kg & \\
\hline Plant protection products & Bottle & \\
\hline Total depreciation & - & \\
\hline Labor & Working day & \\
\hline Other costs & - & \\
\hline Total cost & - & \\
\hline
\end{tabular}

Question 4. Could you please tell about Revenues, Costs, and Profits in harvest stage for 1ha

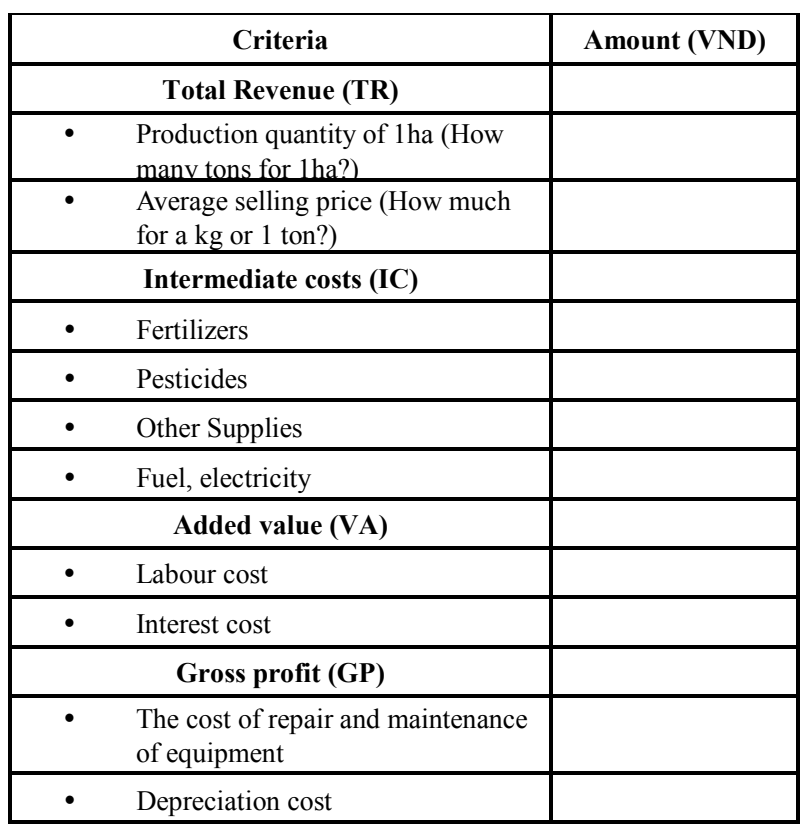

Thanks for your valuable information,

Date ...... month ...... year 20

\section{Interviewer}

Form $A_{1}$

\section{B2. SURVEY FORM}

\section{(FOR VALUE CHAIN OF EXPORT \\ AGRICULTURAL PRODUCTS)}

(INFORMATION FOR COLLECTORS)

\section{Kính thưa Ông/Bà.}

Kinh mong Ông/Bà dành it thời gian cung cấp các thông tin về hoạt động thu mua nông sản. Những thông tin quý báu của Quý Ông/Bà sẽ đurợc bảo mật tuyệt đối chỉ dùng để tổng hơp, phân tích, xủ lý chung và vào muc đích nghiên cúu khoa hoc.

Xin Ông/Bà vui lòng cho biết một số thông tin:

Please tell some information:

\section{GENERAL INFORMATION}

1. Name of collector:

2. Address:

3. Kind of agricultural product:

4. Type of trade:

\begin{tabular}{cccc}
\hline Type & Individual & Co-operative & Enterprise \\
\hline $\mathbf{1} \square$ & $\mathbf{2} \square$ & $\square$ \\
\hline
\end{tabular}

II. COLLECTING INFORMATION

Could you please tell about Revenues, Costs, and Profits in harvest stage for 1 ton

\begin{tabular}{|c|c|}
\hline Criteria & Amount (VND) \\
\hline \multicolumn{2}{|l|}{ Total Revenue (TR) } \\
\hline - $\quad$ Collecting quantity (How may tons?) & \\
\hline - The selling price to the enterprise (On & \\
\hline \multicolumn{2}{|l|}{ Intermediate costs (IC) } \\
\hline - The cost of buying & \\
\hline $\begin{array}{ll}\text { - } & \text { Transportation costs (calculated into } \\
& \text { Logistics cost) }\end{array}$ & \\
\hline $\begin{array}{l}\text { - The cost of preservation (Calculated } \\
\text { into Logistics cost) }\end{array}$ & \\
\hline \multicolumn{2}{|l|}{ Added value (VA) } \\
\hline $\begin{array}{l}\text { - The cost of loading and unloading } \\
\text { (Calculated into Logistics) }\end{array}$ & \\
\hline $\begin{array}{l}\text { - } \begin{array}{l}\text { Packaging cost (Calculated into Logistics } \\
\text { cost) }\end{array} \\
\end{array}$ & \\
\hline - $\quad$ Contact cost & \\
\hline \multicolumn{2}{|l|}{ - $\quad$ Other costs } \\
\hline \multicolumn{2}{|l|}{ Gross profit (GP) } \\
\hline - Depreciation cost for transportation means & \\
\hline
\end{tabular}

Thanks for your valuable information

Date ...... month ...... year 20

\section{Interviewer}




\section{B3. SURVEY FORM}

\section{(FOR VALUE CHAIN OF EXPORT AGRICULTURAL PRODUCTS)}

\author{
(INFORMATION FOR EXPORTERS)
}

\section{Kính thưa Ông/Bà.}

Kinh mong Ông/Bà dành it thời gian cung cấp các thông tin về hoạt động xuất khẩu nông sản. Nhũ̃ng thông tin quý báu của Quý Ông/Bà sẽ đuợc bảo mật tuyệt đối chỉ dùng để tổng hợp, phân tích, xử lý chung và vào muc đích nghiên cúu khoa hoc.

Xin Ông/Bà vui lòng cho biết một số thông tin:

\section{GENERAL INFORMATION}

1. Name of export enterprise:

2. Address:

3. Kind of agricultural product :

\section{INFORMATION ON EXPORTING}

\section{Could you please tell about Revenues, Costs, and Profits in harvest stage for 1 ton}

\begin{tabular}{|ll|l|}
\hline \multicolumn{1}{|c|}{ Các tiêu chí } & \multicolumn{1}{c|}{$\begin{array}{c}\text { Thành tiền } \\
\text { (VND) }\end{array}$} \\
\hline$\bullet$ & $\begin{array}{l}\text { Total Revenue (TR) } \\
\text { procurtity of goods for export (How many tons?) }\end{array}$ & \\
\hline$\bullet$ & FOB export price (On average) & \\
\hline & $\quad$ Intermediate costs (IC) & \\
\hline$\bullet$ & The buying cost for exporting & \\
\hline$\bullet$ & $\begin{array}{l}\text { Transportation costs (calculated into } \\
\text { Logistics cost) }\end{array}$ & \\
\hline$\bullet$ & $\begin{array}{l}\text { The cost of storage (Calculated into } \\
\text { Logistics cost) }\end{array}$ & \\
\hline & $\quad$ Added value (VA) & \\
\hline$\bullet$ & $\begin{array}{l}\text { The cost of loading and unloading } \\
\text { (Calculated into Logistics cost) }\end{array}$ & \\
\hline$\bullet$ & $\begin{array}{l}\text { The cost of customs procedures } \\
\text { (Calculated into Logistics cost) }\end{array}$ & \\
\hline$\bullet$ & $\begin{array}{l}\text { Packaging cost (Calculated into } \\
\text { Logistics cost) }\end{array}$ & \\
\hline$\bullet$ & Contact cost & \\
\hline$\bullet$ & Other costs & \\
\hline & Gross profit (GP) & \\
\hline$\bullet$ & Depreciation cost for transportation & \\
\hline & & \\
\hline
\end{tabular}

Thanks for your valuable information,

$$
\text { Date ...... month ...... year } 20
$$

\section{Interviewer}

\section{REFERENCES}

[1] Bui Huu Duc (2008), Developing agricultural markets in the conditions of our country joining the World Trade Organization, the Communist Review, No. 788 June, page. 60-64, 2008.

[2] Tran Tien Khai (2011), Analyzing the value chain and the agricultural sector, Economic curriculum Fulbright.

[3] Tran Tu Luc (2013), Value chain analysis of Quang Binh Rubber products, Science and technology topics grassroots level, Quang Binh University.

[4] Tran Tu Luc (2013), Strategic for upgrading value chain of Quang Binh Rubber products, Journal of Science Education, University of Da Nang Pedagogy.

[5] Ministry of Agriculture and Rural Development (2012), Summarizing Conference on the work of the sector in 2012 and Development Plan in 2013.

[6] Hoang Thi Thanh Nga (2009), Upgrading strategy for the rubber value chain of smallholder in Bo Trach Distric, Quang Binh Province

[7] World Bank (2006). Report of promoting rural development in Vietnam, 2006.

[8] Vo Phuoc Tan (2004), Consumption ways of agricultural products in the Southeast of VietNam. The situation and the innovative solutions required in accordance economic restructuring in Vietnam. Scientific the research article of the Ministry of Commerce level.

[9] Pham Chau Thanh, Vo Phuoc Tan, and Pham Xuan Thu, Vietnam fruits production and exports based on the Global Gap \& ISO ISO 22000 Standards towards sustainable development, ANQ 2014 Scientific Paper.

[10] Pham Chau Thanh, Vo Phuoc Tan, and Pham Xuan Thu, Enhancing the quality of Vietnam export agricultural products based on the Global Gap and ISO 22000 Standards towards sustainable development, ANQ 2013 Scientific Paper.

[11] Nguyen Hong Thu (2013), Developing agriculture and rural in Japan- Experience lesson for Vietnam, Website of the Southern Institute of Science, Engineering and Technology, at http://iasvn.org/homepage/Phat-trien-Nong-nghiep,-nong-th on-cua-Nhat-Ban---kinh-nghiem-cho-Viet-Nam-2392.html.

[12] Website of Ministry of Agriculture and Rural Development, www.argoviet.gov.vn.

[13] Website of GSO (www.gso.gov.vn).

[14] Dang Quang Vinh (2012), Project "Research on building policy recommendations to support development of small and medium enterprises in the agricultural sector - phase 2 and 3", Institute of Policy and Strategy for Agriculture and Rural Development (IPSARD), Page. 4 